\title{
Research Paper Production and disposal of paddy in Raigad district - An economics analysis
}

See end of the paper for authors' affiliations

Correspondence to :

\section{P. J. Kshirsagar}

Department of Agricultural Economics, College of Agriculture, Dr. B.S. Konkan Krishi Vidyapeeth, Dapoli (M.S) India Email: sagartarang@ rediffmail.com

Paper History :

Received : 08.01.2020;

Revised : 15.02 .2020

Accepted : 22.02 .2020
ABSTRACT : An attempt has been made to study the economics of production and disposal pattern of paddy in Raigad district of Maharashtra, was undertaken with a sample of 120 paddy growers selected randomly from 4 tahsils of Raigad district.It was observed from the study that per hectare cost of cultivation of paddy at cost $C$ was the highest in the small group (Rs.109925) followed by large, (Rs. 104358) and in medium group (Rs. 103741), respectively while it was Rs. 106008 at overall level. The average yield and gross returns per hectare was found to be high in case of medium farmers. The benefit cost ratio of paddy at input cost was 0.99 in small group, 1.15 in medium and 1.16 in large group, while it was 1.10 at overall level. However, the benefit cost ratio at cost ' $\mathrm{C}$ ' was estimated to 0.51 at small farmer level, where as it was work out to 0.56 and 0.54 for medium and large farmers, respectively indicating that cultivation of paddy crop was economically beneficial at farm business income only. The pattern of disposal indicated that, at the overall level, 47.49 per cent of the total produce of paddy was marketable/marketed surplus. The proportion of paddy used for home consumption was accounted to 39.91 per cent.

KEY WORDS : Economic analysis, Paddy, Benefit cost, Disposal, Marketable, Marketed surplus

How To Cite This Paper : Kshirsagar, P.J., Kinhale, C.P., Talathi, J.M., Torane, S.R. and Dhekale, J.S. (2020). Production and disposal of paddy in Raigad district - An economics analysis. Internat. Res. J. Agric. Eco. \& Stat., 11 (1) : 94-101, DOI : 10.15740/HAS/IRJAES/11.1/94-101. Copyright@ 2020:HindAgri-Horticultural Society. 